in connexion with the celebrations to commemorate the centenaty of the discovery of the Victoria Falls by David Livingstone and the beginning of the systematic exploration of the interior of Africa north of the Zambezi. The Congress will, as at its previous sessions, be divided into three sections concerned with: (I) Quaternary geology, \&c., (2) Human palaeontology, (3) Prehistoric archaeology. The business of this session will include symposia on such subjects as the Kalahari sands, their definition, age, distribution, \&c., the early pebble tool cultures, the application of the $\mathrm{C}_{4} 4$ method of dating to African prehistoric cultures. There will also be discussions on discoveries made since the last session, and on research programmes in prehistory and kindred subjects, control of excavations, and the care and protection of sites. Delegates attending the Congress will have an opportunity of visiting the main pre- and proto-historic sites in the Rhodesias and if possible in the Belgian Congo.

The organizing secretary for this meeting is Dr. J. D. Clark, Curator of the RhodesLivingstone Museum (P.O. Box 124, Livingstone), to whom inquiries and applications should be addressed.

\title{
A Survey of the Training of the Ministry in Africa
}

SuRveYs of theological education in Africa were undertaken under the auspices of the International Missionary Council in 1950 and 1953, and Reports of these surveys have recently been made available for private circulation. Part I, by the Rt. Rev. Stephen Neill, M.A., D.D., concerns East and West Africa which he visited in 1950. Part II is the report of a commission, under the chairmanship of Dr. M. Searle Bates, who studied the subject in 1953 in Angola, the Belgian Congo, French West Africa, French Equatorial Africa, Liberia, Mozambique, and Ruanda-Urundi.

Bishop Neill in his survey gives specific details of established and projected training schools, with suggestions for further development, while Dr. Bates provides a more general picture of ministerial training and its present inadequacies against a background of changing social and economic conditions, political considerations, educational systems and linguistic problems in the colonial territories visited.

The main conclusions and recommendations of the two reports vary only in detail. They point out that there is everywhere a lack of suitably qualified teaching staffs, and that a higher standard of general education to stimulate recruitment of suitable candidates for ordination is urgently required. Improvements in the standards of living for all types of ministry are urged.

The question of an improved training programme is dealt with in great detail, and stress is laid on the need for planning it to meet the special requirements of African life and thought. It is recommended that many more African teachers, after receiving higher theological training abroad, should take their places on the staffs of training colleges. It is considered of great importance that there should be the fullest possible cooperation and consultation between the various churches regarding training.

\section{Area Research in Contemporary Africa}

A conference was held at Princeton University (U.S.A.) in October I953, sponsored jointly by the National Research Council and the Social Science Research Council. Its theme was 'Stability and Change in African Society', and among the 68 participants were representatives from the East African Institute of Social and Economic Research, from the Commission for Technical Cooperation in Africa (C.C.T.A.), from IRSAC, from Oxford University, and the University of Natal. Discussion was centred on factors of stability and change 
in political, religious, and economic and social institutions, and was based on questions raised in the papers written by younger scholars who had recently engaged in field research in Africa, which had been circulated in advance of the conference.

In addition to the discussion of substantive questions, extensive consideration was given to the special problems of field research in Central Africa and to the development of African studies in the United States.

\section{'African News'}

Mrs. RUth C. SLOAN, who will be known to many Africanists for her liaison work on research and information in the African field in the United States State Department, has relinquished her official duties in order to establish an independent information service on African and Near Eastern affairs under the title 'Ruth Sloan Associates ', 420 I Massachusetts Avenue, N.W., Washington, D.C. A monthly news-sheet is published which contains brief articles on contemporary events and situations in all parts of Africa, notes on conferences and study ptogrammes related to Africa and sponsored in the United States, digests of news items from African and European publications and a short bibliography of recent books on Africa.

\section{Records of African Music}

THE Ethnic Folkways library of recorded music includes records of the traditional music of all peoples; each collection of records is accompanied by a descriptive booklet, written by an authority in the field, which provides an account of the ethnic and social background of the people whose music is represented. A recent item is entitled Drums of the Yoruba of Nigeria; it was recorded by Mr. William Bascom of Northwestern University, Evanston, Illinois, and is accompanied by an explanatory leaflet which includes a brief account of the Yoruba people, notes on the recordings and photographs of the various types of drums and of a number of actual Yoruba drummers.

Enquiries should be addressed to Folkways Records and Service Corp., II 7 West 46th Street, New York 36, N.Y., U.S.A. 